\title{
Women in Bangladesh Civil Service: Stumbling Blocks towards the Way of Participation
}

\author{
Jannatul Ferdous \\ Department of Public Administration, Comilla University, Comilla, Bangladesh
}

\section{Email address:}

sohanishefa@gmail.com

\section{To cite this article:}

Jannatul Ferdous. Women in Bangladesh Civil Service: Stumbling Blocks towards the Way of Participation. Social Sciences. Vol. 3, No. 5, 2014, pp. 177-182. doi: 10.11648/j.ss.20140305.15

\begin{abstract}
Bangladesh is considered as a developing country, half of the total population comprises women. Their socioeconomic condition is poor. The position of women in the family is very complex regarding different aspects like tradition, security, and equality of men-women, social dignity and for multifaceted stress. Here participation of men and women social development activities is not equal. Many activities of women are not counted as productive work. Consequently, socioeconomic development cannot be achieved in the real sense without the strong participation of women at the decision making activities in society. According to practice of our society, Women are leg behind culturally, socially and economically. All kinds of conveniences and chances are needed to be delivered to ensure active participation of women in all spheres of life. The government is the largest employer in Bangladesh. Therefore, women's inclusion in different cadre service is very noteworthy and needs superior attention from for the appointment of women in Bangladesh Civil Service (BCS). The Government of Bangladesh (GOB) has already taken some policy measures to ensure justifiable participation of women in the civil service arena. A quota system was introduced by GOB to increase participation of women in the government service sector. Yet the presentation of women in government services has not got a reasonable level. Hence, detecting the stumbling blocks of women's participation in the BCS and take necessary steps to remove the stumbling blocks is the main purpose of my research. An effort has been made in this paper to evaluate the prevalent employment status of women in BCS cadres with a focus on the stumbling blocks faced by the women civil servants which discourage participate them in the BCS.
\end{abstract}

Keywords: Civil Service, Women, Bangladesh, Participation

\section{Introduction}

The participation of female executives has increased globally over the half of the century. But, a number of studies show under representation of women at the senior level because of structural and cultural barriers prevailing within the organizations [1]. The Wide disparity between male and female representation is very common in most of the third world countries. Women got a very little access to public services. The executive positions are generally occupied by the male and fewer women employed in the civil service, but occupy a very little number in the key decision making position of the service [2]. Present research indicates that women's participation in the civil service faces a number of barriers which leads to lower representation.

Since the independence of Bangladesh, the Government has been trying to gain development. But development requires equal participation of man and women. In
Bangladesh, men take the lion's share of participation compared to women. While women constitute half of the population, they still constitute a big workforce whose employment is regarded as balancing properly. Women need long way to go to attain a good number of participants. The present study provides some measures to make the civil service of Bangladesh balancing and equal access to public employment.

\section{Conceptual Framework}

The participation of women in Bangladesh Civil Service (BCS) is not in satisfactory level. The Government of Bangladesh (GOB) has already taken some attempts to ensure justifiable participation of women in the civil service arena. Before going on Women in Bangladesh Civil Service it is essential to define the concepts, gender, women, civil service and reservation system. 


\subsection{Gender}

Understanding the gender issues is important because it is the key factor of development. Basically, the differences between man and women are determined biologically, then socially.

Sex defines biological differences between man and women. Gender is socially determined psychological and personal features relating to man and women. A gender relation defines appropriate behaviors or activity for male and female which is socially determined. Gender also refers to both male and female and the interactions between them. Different factors like religious, economic, cultural, sociological and political factors produced gender differences and every society has created gender differences [2].

\subsection{Women}

Women are discriminated through customs and laws, represents them as disadvantaged and vulnerable social groups. They are treated with discrimination because of their gender. It is widely accepted today like class and race/ ethnicity, gender is a source of inequality [3]. Women constitute closely half of the entire population and prospective also. Thus, without the active participation of women at the decision making level in society the socioeconomic development of the country is impossible. Women are always staying behind economically, socially and culturally in Bangladesh. All sorts of conveniences and breaks are to be provided to them, to confirm the active participation of women in all spheres of life [4].

\subsection{Civil Service}

Generally Civil service of a country excludes defense service, although some civil servants work in defense ministry and its various departments. It includes all permanent functionaries of government. A member of civil service cannot be a holder of political or judicial office. In a group, the civil servants of a state called civil service [5].

According to Rai and Singh, the civil service is a body of neutral and professional experts in administration, which devoted to serve without affection to its personal gains or without reference to class interests or party political sights [6]. The civil service - that organizes the administrative portion of the government that accomplishes the government's vision and mission.

\subsection{Reservation System}

Gender and minority issues of public sector employment in most developing countries needed to be analyzed critically. Constitutional provisions usually declare equality between men and women and forbid any discrimination on the basis of sex or other considerations in the ground of recruitment and promotion of government employees. So far, different barriers like social, cultural, and educational and security paves the way of women from enjoying fully their constitutional rights and agreements [7]. Against this backdrop, equal participation has become a key concern. To increase the poor participation of the backward section of the society in the civil service, some developing countries have made some important arrangements. To minimize the drawbacks faced by those the constitutions of such countries have allowed reserving a specific percent of their posts in the public services for women.

\section{Objectives of the Study}

1) To present the status of female officers in the Bangladesh Civil Service (BCS).

2) To examine the women development policy adopted by Bangladesh Government.

3) To find out the factors those affect the prospects of women in Bangladesh Civil Service (BCS).

4) To suggest some measures to reduce the stumbling blocks towards the way of participation.

\section{Methodology}

The paper has been developed on the basis of reviewing secondary sources in this arena. Data were collected from various published forms of books, journals, newspapers, government circulars, research reports, annual reports of Bangladesh Public Service Commission (BPSC) and Ministry of Public Administration (MoPA) and internet browsing.

\section{Background of Female Officers in Bangladesh Civil Service (BCS)}

The origin of the present BCS taken place during the British rule in the Indian Sub-continent. The civil service system developed in Pakistan inherited to Bangladesh era, which was an inheritance of the Indian Civil Service (ICS). The ICS was entirely staffed by men. No entrance of women in the ICS till 1935. The Civil Service of Pakistan sustained its evolution and brings the tradition of the ICS. During the Pakistan era, only unmarried women account for only about mostly are entitled to work in the four services. The main objective behind this was to keep women confined mostly desk-bound jobs. In this period, it is believed, because of the broad field of women's visits and inspections, called for the maintenance of law and order and the collection of revenues which were not suitable for this kind of work. So women are not fit to perform in levels or administrative cadres. It is clear that women are four services, namely, 1) Audit and Accounts Service, 2) Railway Accounts Service, 3) Military Accounts Service, 4) Income Tax and Postal Service, will only be considered to have been mentioned in the service of the Civil Service Recruitment Rules. Because of this resolution that women could not work in various important services including many other Class I Civil Service, the Civil Services of Pakistan, the Pakistan Foreign Service and were absolutely lacking of women [4]. 
In addition, female candidates must resign from service after they marry and remarry under conditions that are to be assigned. The Pakistan government's argument for a married woman to keep her skills up to the level of quality will not be possible. This section of the Recruitment Rules hinders the way of educated women in Pakistan and they are deprived of their basic rights to enter a profession. This is a very small number of women cadres could enter service [8].

\section{Government Policy and the BCS Women Status}

After the emergence of Bangladesh, it was found that, in the civil service, women were under represented. Recognizing this problem, in each case of Bangladesh Constitution to provide equal opportunities for women and men has important provisions. Moreover, the government adopted quotas or reservation of posts for women in entering the civil service and took many policies not only to increase women's representation in the civil service but to integrate women into the mainstream of development.

\section{The Constitutional Guarantee of Equal Job Opportunities}

Bangladesh Constitution to assure equal treatment for men and women in every aspect of life. Article -29 of the Bangladesh Constitution states that:

1) "There shall be equality of opportunity for all citizens in respect of employment or office in the service of the Republic".

2) "No citizen shall, on grounds only of religion, race, caste, sex or place of birth, be ineligible for, or discriminated against in respect of, any employment or office in the service of the Republic".

3) "Nothing in this article shall prevent the State from-(a) making special provision in favour of any backward section of citizens for the purpose of securing their adequate representation in the service of the Republic;(b) giving effect to any law which makes provision for reserving appointments relating to any religious or denominational institution to persons of that religion or denomination; reserving for members of one sex any class of employment or office on the ground that it is considered by its nature to be unsuited to members of the opposite sex" [9].

\section{Quota Policy in BCS}

After the birth of Bangladesh, though there were no recruitment rules were framed, number of recruitment was made. An interim recruitment policy was framed in 1972 for the recruitment to various posts and services. To achieve equitable presentation of people was the major thrust of that policy. There was quota reservation for different categories like- district quota on the basis of population, quota reservation for war-affected women, tribal and freedom fighters. This policy had undergone changes from time to time [10].

Bangladesh government was first promulgated Reservation of quota for women in public services under a notification of the government in 1976. With the declaration of 1975 as the International Year of women and $1976-85$ as the UN decade of Women, it was a straight consequence of a greater national awareness created about the importance of women's role in the development procedure. The order quotes as-"There shall be 10 percent quota for women candidates in all categories of vacancies subject to their fulfillment of basic qualification. This, however, will not apply in respect of recruitment to technical post, post in defense services and in such other post as may be considered unsuitable by the Ministry concerned'[11].

The provisions for quota reservation by GOB shown at below table:

Table 1. Quota Reservation Policy, 1997

\begin{tabular}{llcc}
\hline SL no & Type of Quota & Class I and II Gazetted Posts (Percentage) & Class III and IV Non Gazetted Posts (Percentage) \\
\hline I & Qualification (out of District Quota) & 45 & 10 \\
II & $\begin{array}{l}\text { Physically handicapped/mentally } \\
\text { Retarded (out of District quota) }\end{array}$ & 30 & 30 \\
III $\quad$ & & \\
& $\begin{array}{l}\text { District or Regional quota (based on } \\
\text { Population): The Fighters of the }\end{array}$ & & 15 \\
& Liberation War or in the absence of & & 05 \\
& them martyred fighter's children & 10 & 10 \\
& Women & 05 & 30 \\
& Tribal & & 100 \\
& Ansars/VillageDefence members & & \\
& Remaining (for the general candidates & & \\
& for the District) & 10 & \\
& Total & 100 & \\
\hline
\end{tabular}

Source: [12],[10]

Currently, 56\% of public services is covered by quotapreferences, thus only $44 \%$ jobs are left for recruitment based on qualification. Additionally, $1 \%$ is preserved to physically disabled citizens [13]. 
So, the GOB for women, in non-gazetted posts 15 per cent quota and 10 per cent quota for the employment of reserves gazetted posts as special measures to enhance the participation of women in the civil service [14]. The government's positive goals and desires for attaining gender equality in the civil service, this policy actually reveals that.

\section{Status of Women in the Civil Service}

The presentation of women in Bangladesh civil service shows a frustrating picture. Bangladesh Civil Service divided into four classes including class I, II, III and IV depending on job responsibility, educational qualification and pay issues [15]. The below table depicts class-wise female officers and employees presentation.

The above table shows that, there is a very slow increase in the participation of women since 1971 in BCS. The below table no-5 express the number of male and female candidates who got chances in the civil service in different BCS examinations.

Table 2. Class-wise Number of Female Representation, 2008

\begin{tabular}{|c|c|c|c|c|}
\hline Class & Ministry/Division & Departments/ Directorates & Autonomous bodies/ Corporations & Total \\
\hline Class I & 400 & 8746 & 4449 & 13595 \\
\hline Class II & 279 & 3445 & 2338 & 6062 \\
\hline Class III & 342 & 175963 & 6070 & 182383 \\
\hline Class IV & 289 & 18633 & 2682 & 21604 \\
\hline Grand Total & 1310 & 206789 & 15545 & 223644 \\
\hline
\end{tabular}

Source: [16]

Table 3. Number of Selected Male and Female Candidate in BCS

\begin{tabular}{ccccc}
\hline Name of BCS Exams & Male & Percentage & Female & Percentage \\
\hline $26^{\text {th }}$ BCS & 703 & 66.13 & 360 & 33.87 \\
$27^{\text {th }}$ BCS & 2417 & 74.62 & 822 & 25.38 \\
$28^{\text {th }}$ BCS & 1520 & 69.41 & 670 & 30.59 \\
$29^{\text {th }}$ BCS & 1232 & 71.54 & 490 & 28.46 \\
$30^{\text {th }}$ BCS & 1623 & 68.57 & 744 & 31.43 \\
Total & 7495 & 70.83 & 3086 & 2190 \\
\hline
\end{tabular}

Source: [17]

The above table reveals that, these five BCS Examinations 29.17 percent female candidates were selected. So it can easily identify that women's representation at all levels of civil service are very poor.

\section{Factors Affecting the Prospects of Women in Bangladesh Civil Service (BCS)}

The reason behind the inadequate representation of women in the civil service staff is multi-dimensional. Women cadre service officers, which arise both in the home and office facing multiple problems. Women's sidelined position in the BCS could be seen as restricting from a a difficult relationship of different issues, including historical, attitudinal, traditional, socioeconomic and organizational also. Some influencing factors are debated below:

\subsection{Lack of Appropriate Policies}

Policies and procedures regarding the recruitment, transfer, training and deputation of female civil servants is suffering from inappropriateness. The existing policy is very much unfriendly to women and discourages them not to join the civil service.

\subsection{Negative Attitude of Male Colleagues}

Our society is highly a male controlled society. Society's values, norms, religious beliefs do not allow women to be in decision making positions. Men cannot accept women as mentally bosses and colleagues. Men's fit enough to take the challenge and make the decision is in the top positions. Male colleagues have a tendency to dominate their female colleagues, and in many cases the distribution of unequal treatment women receives official duties. These experiences create negative impact on them.

\subsection{Family Responsibilities}

Due to the cultural heritage of the responsibility lies with the women in a family. Sometimes they give priority to the family when they need to choose between the family and career. She has to look after his office and the house, because it is a working woman, a double burden. Full-time working women from domestic responsibilities are not forgiven. This office is an obstacle to maintaining a high standard of performance, which takes away a big part of their productive energy. Women are expected to play at home and office due to the multiple roles, it is difficult to perform efficiently [4].

\subsection{Lack of Adequate Facilities and Services}

Lack of adequate facilities and services like day care centres, separate washroom for female staff; amiable working atmosphere; transport and accommodation, etc. for working women are not duly considered and that discourages women to join the civil service [18]. 


\subsection{Widespread Touring}

Remote areas are often mandatory tours, night hold, law enforcement, disaster management, emergency duties entails physical and psychological dangers. Men Senior Women officers keeping restrictions, state "important issues" do not depend on them. This approach limits the opportunity for women to hold important positions [19].

\subsection{Security Problems}

Abuse and harassment is a very common affair in Bangladesh. Lack of proper security is a major cause for not to join the civil service. Though it is challenging job, security is a very vital issue for women.

\subsection{Lack of Women's Participation in Policy Making}

Women are absent in policy formulation, implementation and evaluation regarding women's advancement. A sufferer can make a solution of his or her problem the better. Involvement of women in policy making can advance them more, but lack of women's participation in this arena hinders the way of progress.

\subsection{Non Cooperation of Family}

Women face difficulty when posting them at remote place. Then they feel difficulty in performing the household activities, child care and other family commitments. In such situation, non-cooperating attitude of the husband and family members also act as an impediment in continuing and joining the job.

\subsection{Lack of Awareness Building Prgramme}

There is a lack of mass awareness campaign programs and gender sensitive code of conduct also. This campaign specially needed to male civil servants. But such awareness program is still missing in Bangladesh.

\subsection{Societal Backwardness}

There exists a belief, staring from the employer to the common people that women are unsuitable for administrative and challenging jobs, owing to the cultural alignment. Accordingly, by the community women are not accepted as a 'magistrate' or 'police officer'. Very rarely, people inspire women to join or continue their jobs in such positions. There have developed close mindedness in both males and females because of social preconceptions and old-fashioned approaches generated by cultural conditioning along with norms, values and the socialization process. Negative social approaches towards female professional career create low career interest among female [4].

\section{Recommendations}

The policy makers of Bangladesh tried a lot to ensure gender equity in public service through constitutional provisions and quota systems. The determination of mainstreaming of gender in the civil service at the entry level; the policy give the impression to work. Though, the preferred result to increase women's participation at all levels of decision-making as well as policy level has not been a long way to go. The recommendations may help to increase women's participation and remove the barriers to entry in the civil service.

1. Proper policy should be taken regarding promotion, transfer and deputation. The policy should be friendly to the family life of the female civil servants.

2. The working atmosphere should be convenient to the women civil servants. They should be given enough hostel facilities, housing facilities, separate rest room, separate toilet, day care center for maintaining children's and transport facilities should be provided.

3. The typical mindset of men towards women should be changed. Women should encourage joining the civil service.

4. Family members should cooperate women to join the civil service and continue the job without any disturbance.

5. A strong national campaign may be promoted against the traditional socio-cultural and religious norms to inspire and support the women to ensure equal job opportunities.

6. Media should help in transforming information regarding women friendly policies of government and increase social awareness to change the mindset.

7. Female quota should be increased from 10 percent to 15 percent at the entry level in the civil service to minimize the gap between male and female.

8. The prevailing female quota policy cannot utilize the quota in many recruitments of Bangladesh Civil Service properly. Therefore, prominence should be assumed to the full employment in the quota.

9. Women should be given enough chances to entry and perform at the policy making level. Through this, they can solve their problems well.

10. In the place of work, female colleagues faced difficulty by the male colleagues. Gender sensitivity training may be promoted, With the intention of shape up conscious of gender issues at work place.

11. Educational facilities should be given to the grassroots level women, who are deprived of this facility. Through proper education, they can represent them in a proper job position.

12. In Bangladesh, The education sector is suffering from poor planning. Their needs proper planning in academic activities that ensures job opportunity and increase women empowerment.

\section{Conclusion}

Women's employment in the country's economic and social progress plays a significant role. Bangladesh, a woman's life is dominated by a patriarchal and patrilineal social intercom system. Moreover, the employment status of women is still lower than the expected level. Over the years, In Bangladesh the backwardness to overcome issues related 
to women as well as women's social, cultural and economic sectors to achieve considerable progress has been made. Despite this progress, women are still a big part of the country's social, cultural, economic, and political life has been empowered to participate actively. Health, nutrition, education, employment, and political participation, as indicated by the official statistics, gender inequality is prevalent in all spheres of life. Lack of choice of creative techniques tailored to the context and to deliver power to depart from the orthodoxy of, major obstacle to the development of the country. In addition, the factors responsible for not achieving targets such as reducing gender inequality. Women's equal participation in the civil service, will help them empower more economically and status also. Government has to be more sincere and attentive to implement the policy effectively and increase the participation of women in the civil service.

\section{References}

[1] MN K., \& Mukulu E. (2012). Perceived Organisational Barriers to Women Career Progression in Kenya's Civil Service. International Journal of Advances in Management and Economics, 1 (6), 203-213.

[2] Kabir, L. (2013). Women's Participation In South Asian Civil Services: A comparative analysis of India, Pakistan and Bangladesh. Dhaka: A H Development Publishing House.

[3] Mahtab, N. (2007). Women in Bangladesh: From Inequality to Empowerment. Dhaka: A H Development Publishing House.

[4] Jahan, M. (2007). Gender Mainstreaming in Bangladesh Civil Service: Prospects and Constraints. Asian Affairs, 29 (1), 4172 .

[5] Wahhab, M.A (2009). Civil Service Recruitment Policy in Bangladesh; A Critical Analysis. Paper submitted for NAPSIPAG International Conference. Held on 11-13 December, 2009, Malaysia.

[6] Rai, h. and Singh, S.P. (1979). Current Ideas and Issues in Indian Administration, A Development Perspective. New Delhi : Uppal Punishing House.
[7] Rahman, A.T.R (2001). Reforming the Civil Service for Government performance: A partnership Perspective. Dhaka: University Press Limited.

[8] Mahtab, N. (1995). Women in Bangladesh Civil Service Cadres (1972-1986). In Huq J. et. al. (eds.) Women in Politics and Bureaucracy (pp 86-99). Dhaka: Women for Women.

[9] Government of Bangladesh. (2011). The Constitution of Bangladesh. Dhaka: GOB.

[10] Ali, S.A.M.M. (2004). Bangladesh Civil Service: A PoliticalAdministrative Perspective. Dhaka: University Press Limited.

[11] Khan, S. (1988). The fifty percent: Women in development and policy in Bangladesh. Dhaka: University Press Limited.

[12] Yasmin, N. (2010). Quota System in Bangladesh Civil Service: An Appraisal. Masters Dissertation. Dhaka: BRAC University.

[13] Habib W. B. \& Chakraborty P. (2013, July 13). Review of Quota System Government sits on PSC recommendation. The Daily Star. Retrieved from http://archive.thedailystar.net/beta2/news/govt-sits-on-pscrecommendation/

[14] Khan, M. R. \& Ara F. (2005). Direct Recruitment in the Cadre Services in Bangladesh: An Overview. Pakistan Journal of Social Sciences, 3 (7), 915-921.

[15] Ahmed, S. G. (1986). Public Personnel Administration in Bangladesh. Dhaka: Dhaka University Press.

[16] Ara, F. (2012). Women in Bangladesh Civil Service: Present Status and Challenges. Society \& Change, 6(1), 62-70.

[17] Banglaseh Public Service Commission (2011). Annual Report. Dhaka: Public Service Commission.

[18] Karim M. R. (2008). Women in Bangladesh Civil Service: Vulnerability and Challenges. Paper presented for the 12th World Congress of Rural Sociology, Goyang Korea. Retrieved from http://www.irsa-world.org/XII/papers/1-2.pdf

[19] Jehan, S. A. (2011). Reflection of Structural and Cultural Mindset in Representation of Women in Bangladesh Civil Service. SAARC Journal of Human Resource Development, 7(1), 83-93. 